\title{
PENERAPAN MODEL PEMBELAJARAN KOOPERATIF TIPE TALKING CHIPS UNTUK MENINGKATKAN HASIL BELAJAR SISWA PADA MATA PELAJARAN PAI
}

\author{
Rini Fadilah \\ Mahasiswa Jurusan PAI UIN Sunan Gunung Djati \\ Jl. A. H. Nasution No. 105, Bandung Jawa Barat \\ Email: rinifadilah56@gmail.com
}

\begin{abstract}
This study aims to determine student learning outcomes before and after using the cooperative learning model of talking chips. The method used in this study is classroom action research (CAR) with the implementation procedure for III cycles in which each cycle is conducted in two meetings. Data collection techniques consist of tests, interviews and documentation. The results of this study indicate an increase in each meeting in each cycle. Judging from the classical learning completeness of students after the pretest-posttest at the 1st meeting was $13.33 \%$ and $43.33 \%$, up to meeting 5 was $50 \%$ and $90 \%$.
\end{abstract}

Keywords:

Talking Chips, Learning Outcomes

\begin{abstract}
Abstrak :Penelitian ini bertujuan untuk mengetahui hasil belajar siswa sebelum dan sesudah menggunakan model pembelajaran koopratif tipe talking chips. Metode yang digunakan dalam penelitian ini adalah penelitian tindakan kelas (PTK) dengan prosedur pelaksanaan selama III siklus dimana setiap siklusnya dilakukan sebanyak dua pertemuan. Teknik pengumpulan data terdiri dari tes, wawancara dan dokumentasi. Hasil penelitian ini menunjukan adanya peningkatan pada setiap pertemuan dalam setiap siklusnya. Dilihat dari ketuntasan belajar klasikal siswa setelah pretest-postest pada pertemuan 1 adalah sebesar $13.33 \%$ dan $43.33 \%$, sampai pada pertemuan 5 adalah sebesar $50 \%$ dan $90 \%$.
\end{abstract}

Kata kunci:

Talking Chips, Hasil Belajar

\section{PENDAHULUAN}

Dalam Undang-Undang No. 20 Tahun 2003 tentang Sistem Pendidikan Nasional merumuskan pendidikan adalah usaha sadar dan terencana untuk mengembangkan potensi peserta didik agar memiliki kekuatan spritual keagamaan, pengendalian diri, kepribadian, kecerdasan, ahlak mulia, serta keterampilan yang diperlukan dirinya, masyarakat, bangsa dan negara (Undang-Undang Republik Indonesia tentang Guru dan Dosen).

Pendidikan agama islam disekolah bertujuan agar siswa dapat memahami, mengahayati, meyakini, dan mengamalkan ajaran islam sehingga menjadi manusia muslim yang beriman, bertakwa kepada Allah Swt dan berahlak mulia (Muhaimin, 2012: 78). Mata pelajaran PAI di sekolah mempunyai peranan penting dalam pembentukan watak bangsa, pelajaran PAI dilakukan untuk mempersiapkan peserta didik dalam meyakini, memahami ajaran islam. Pendidikan tersebut melalui kegiatan bimbingan, pengajaraan atau pelatihan yang telah ditentukan untuk mencapai tujuan yang telah ditetapkan (Alim, 2011:4). Dalam kmurikulum 2013 semua mata pelajaran 
harus mencakup aspek spritual, sosial, pengetahuan dan keterampilan. Maka ketika siswa menguasai aspek-aspek tersebut diharapkan dapat mencapai tujuan pendidikan. Adapun tujuan pendidikan yang ditetapkan dalam Undang-Undang No. 20 Tahun 2003 pasal 3 yang berbunyi: Pendidikan nasional berfungsi untuk mengembangkan kemampuan dan membentuk watak serta peradaban bangsa, bertujuan untuk berkembangnya potensi peserta didik agar menjadi manusia yang beriman dan bertakwa kepada Tuhan Yang Maha Esa, berahlak mulia, sehat, berilmu, cakap, kreatif, mandiri, dan menjadi warga negara yang demokratis serta bertanggung jawab.

Untuk mencapai tujuan pendidikan dari mata pelajaran PAI dibutuhkan berbagai aspek pendidikan yang berkualitas. Kualitas pendidikan dipengaruhi oleh kualitas pembelajaran dan keprofesionalan guru dalam memilih model dan metode ketika pembelajaran. Dalam sebuah pembelajaran guru merupakan salah satu komponen utama dalam proses pembelajaran. Agar proses pembelajaran itu bisa menjadi efektif, apabila kegiatan belajarnya itu berpusat pada siswa (Student centered) dan interaksi antara guru dengan siswa itu terjalin dengan baik. Interaksi belajar itu ditandai dengan adanya aktivitas siswa, karena dalam setiap proses belajar siswa harus menunjukan keaktifannya. Keaktifan itu beraneka ragam bentuknya, mulai dari kegiatan fisik yang mudah untuk kita amati sampai kegiatan psikis yang susah untuk diamati. Kegiatan fisik berupa membaca, mendengar, menulis, berlatih keterampilan-keterampilan, dan sebagainya (Dimyati, 2013:45). Menurut Muhibbin Syah (2012:145) faktor yang mempengaruhi belajar siswa dapat dibedakan menjadi tiga macam, yaitu faktor internal yakni kondisi jasmani dan rohani, faktor eksternal yakni keadaan lingkungan sekitar siswa, dan faktor pendekatan belajar yakni jenis upaya belajar siswa yang meliputi strategi, model dan metode yang digunakan siswa untuk melakukan kegiatan pembelajaran.

Agar proses belajar mengajar berlangsung secara efektif dan menyenangkan, seorang guru harus mampu menggunakan model pembelajaran yang dapat mengembangkan interaksi antara guru dengan murid, dimana siswa yang terlibat secara penuh selama proses pembelajaran (student center). Model pembelajaran merupakan pola yang digunakan sebagai pedoman dalam merencanakan pembelajaran di kelas (Agus Suprijono, 2010: 46). Pembelajaran kooperatif merupakan sistem belajar dengan membagi siswa kepada beberapak kelompok dan menekankan kerjasama sesama teman. Pembelajaran kooperatif dikembangkan untuk mencapai hasil belajar berupa prestasi akademik, toleransi, menerima keragaman, dan pengembangan keterampilam sosial (Agus Suprijono, 2013: 61). Talking Chips adalah salah satu model pembalajaran kooperatif yang pertama kali dikembangkan oleh spencer. Talking Chips dalam pembelajaran kooperatif adalah pembelajaran yang dialakukan dalam kelompok kecil yang terdiri dari 4-5 orang, masing-masing aggota kelompok membawa sejumlah kartu yang berfungsi untuk menandai apabila mereka telah berpendapat dengan meletakan kartu tersebut ke atas meja (Darmadi, 2017:103).

Berdasarkan hasil tanya jawab dengan guru PAI di SMPN 4 Cikarang Timur. Telah diperoleh beberapa informasi dari bu Eneng selaku guru PAI di kelas VIII. Beliau 
mengemukakan bahwa ada pembiasaan tadarus bersama sebelum pembelajaran di mulai dan selama pembelajaran PAI di setiap kelas sudah terlaksana dengan baik dan lancar. Dalam melaksanakan pembelajaran pun sudah menyesuaikan dengan silabus. Adapun metode yang sering digunakan setiap kali pembelajaran adalah metode ceramah dan tanya jawab. Akan tetapi, jika di lihat dari nilai ujian siswa kelas VIII pada aspek kognitif sebagian besar rata-rata nilainya hanya mencapai 70. Sedangkan KKM yang ditentukan oleh sekolah adalah 76. Hal ini yang menunjukan bahwa hasil belajar siswa ini belum mencapai KKM dan masih berada pada kategori rendah. Masalah rendahnya hasil belajar siswa ini tentunya harus ditangani dengan serius. Penyebab rendahnya hasil belajar siswa ini diduga dari penggunaan metode pembelajaran yang cenderung masih bersifat konvensional, dimana hanya menggunakan metode ceramah dan tanya jawab. Sehingga mengakibatkan pembelajaran itu menjadi membosankan dimana siswa hanya mencatat dan mendengarkan apa yang guru sampaikan.

Tujuan dari penelitian ini adalah untuk mengetahui bagaimana hasil belajar siswa antara sebelum menggunakan odel pembelajaran kooperatif tipe talking chips dengan yang sudah menggunakan model pembelajaran kooperatif tipe talking chips. Manfaatnya adalah selain untuk memperbaiki kualitas pembelajaran juga menambah pengetahuan tentang macam-macam model pembelajaran yang lebih inovatif.

Maka dari itu, harus ada inovasi pembelajaran yang dirancang sistematis, kritis dan menyenangkan. Pembelajaran yang dirancang sedmikian rupa agar memberikan pengalaman belajar terhadap mental, fisik, dan pengalaman sosial melalui interaksi antar peserta didik, guru, lingkungan dan sumber belajar lainnya dalam rangka mencapai hasil belajar yang optimal. Pembelajaran dengan menggunakan model pembelajaran kooperatif tipe talking chips diharapkan dapat menciptakan susasana belajar yang lebih efektif dan menyenangkan, sehingga tidak membuat siswa merasa jenuh. Maka dari itu guru harus lebih inovatif dalam menggunakan dan memilih metode dan model pembelajaran.

\section{METODOLOGI PENELITIAN}

Penelitian ini menggunakan pendekatan penelitian kualitatif dan kuantitatif. Anas Salahudin (2015) menyatakan, Pendekatan kualtitatif dalam penelitian tindakan kelas ini untuk mendeskripsikan proses kegiatan pembelajaran yang terjadi selama dilapangan, kemudian menganalisis kegiatan pembelajaran yang terjadi dilapangan, dan untuk menyusun hipotesis yang berkenaan dengan konsep pembelajaran berdasarkan data dan informasi yang terjadi dilapangan. Sedangkan untuk kebutuhan analisis lebih lanjutnya yang berkaitan dengan data numerikal (angka) dapat menggunakan pendekatan kuantitatif. Metode yang digunakan dalam penelitian ini adalah penelitian tindakan kelas (Classroom Action Research). Menurut Kunandar (2013: 46), penelitian tindakan kelas adalah suatu rancangan kegiatan yang dilakukan oleh guru di dalam kelasnya sendiri dengan jalan merencanakan, melaksanakan, mengamati, dan merefleksikan tindakan dengan menggunakan beberapa siklus secara kolaboratif dan partisipatif yang memiliki tujuan untuk meningkatkan atau memperbaiki kualitas proses pembelajaran di dalam 
kelas. Menurut Kurt Lewin, penelitian tindakan kelas ini merupakan sebuah rangkaian kegiatan yang terdari dari empat tahap/komponen, yaitu perencanaan, tindakan, pengamatan dan refleksi (Kunandar, 2013: 42). Hubungan dari keempat tahapan tersebut merupakan sebuah siklus, sehinga dalam penelitian ini peneliti melaksanakan sebanyak III siklus, dimana setiap siklusnya dilaksanakan sebayak dua kali pertemuan.

Sumber data dalam penelitian ini menggunakan, Sumber data primer, yaitu data yang langsung dari sumber yang utama seperti kepala sekolah, guru dan siswa di SMPN 4 Cikarang Tmur. Dan Sumber data sekunder, yaitu data yang dikumpulan untuk menunjang sumber utama atau bisa disebut data berupa kumpulan dokumen berupa artikel, jurnal, dokumentasi.

Penelitian ini dilakukan di SMPN 4 Cikarang Timur, Subjek utama yaitu pada siswa kelas 8.5 yang berjumlah sebanyak 30 orang, yang terdiri dari 13 siswa laki-laki dan 17 siswa perempuan. Penelitian ini dilaksanakan pada semester genap, yaitu dari tanggal 23 Februari 2018 sampai dengan 23 Maret 2018. Dalam tabel dapat dilihat jadwal pelaksanaan penelitian selama 4 kali pertemuan, dengan rincian sebagai berikut.

Tabel 3.1 Waktu Pelaksanaan Penelitian

\begin{tabular}{|c|c|c|c|}
\hline Pertemuan & Siklus & Hari/Tanggal & Indikator \\
\hline 1 & $\mathrm{I}$ & $\begin{array}{c}\text { Jumat, } 23 \\
\text { Februari } 2018\end{array}$ & $\begin{array}{l}\text { - Menjelaskan pengertian shalat sunnah. } \\
\text { - Menghafal hadis tentang keutamaan } \\
\text { melaksanakan shalat sunnah. } \\
\text { - Mengidentifikasi hukum pelaksanaan } \\
\text { shalat sunnah. } \\
\text { - Mengklasifikasikan macam-macam } \\
\text { pelaksanaan shalat sunnah. }\end{array}$ \\
\hline 2 & & $\begin{array}{c}\text { Jumat, } 2 \text { Maret } \\
2018\end{array}$ & $\begin{array}{l}\text { - Menjelaskan macam-macam shalat } \\
\text { sunnah berjamaah (Shalat Idain, Shalat } \\
\text { gerhana matahari dan bulan, istisqo). } \\
\text { - Menjelaskan hikmah dari melaksanakan } \\
\text { shalat sunnah. } \\
\text { - Menjelaskan ketentuan dan tata cara } \\
\text { melaksanakannya. } \\
\text { - Mendemonstrasikan pelaksanaan shalat } \\
\text { sunnah berjmaah. }\end{array}$ \\
\hline 3 & II & $\begin{array}{c}\text { Jumat, } 9 \text { Maret } \\
2018\end{array}$ & $\begin{array}{l}\text { - } \text { Menjelaskan macam-macam shalat } \\
\text { sunnah munfarid (Rawatib, tahiyatul } \\
\text { masjid, istikharah). } \\
\text { - Menjelaskan ketentuan dan tata cara } \\
\text { melaksanakannya. } \\
\text { - Mendemonstrasikan pelaksanaan shalat } \\
\text { sunnah munfarid. }\end{array}$ \\
\hline
\end{tabular}




\begin{tabular}{|c|c|c|c|}
\hline 4 & & $\begin{array}{c}\text { Jumat, } 16 \text { Maret } \\
2018\end{array}$ & $\begin{array}{l}\text { - Menjelaskan macam-macam shalat } \\
\text { sunnah yang bisa dikerjakan secara } \\
\text { munfarid dan berjamaah (tarawih, witir, } \\
\text { dhuha). } \\
\text { - Menjelaskan ketentuan dan tata cara } \\
\text { melaksanakannya. } \\
\text { - Mendemonstrasikan pelakasanaan shalat } \\
\text { sunnah yang bisa dilakukan secara } \\
\text { berjamaah dan munfarid. }\end{array}$ \\
\hline 5 & III & $\begin{array}{c}\text { Jumat, } 23 \text { Maret } \\
2018\end{array}$ & 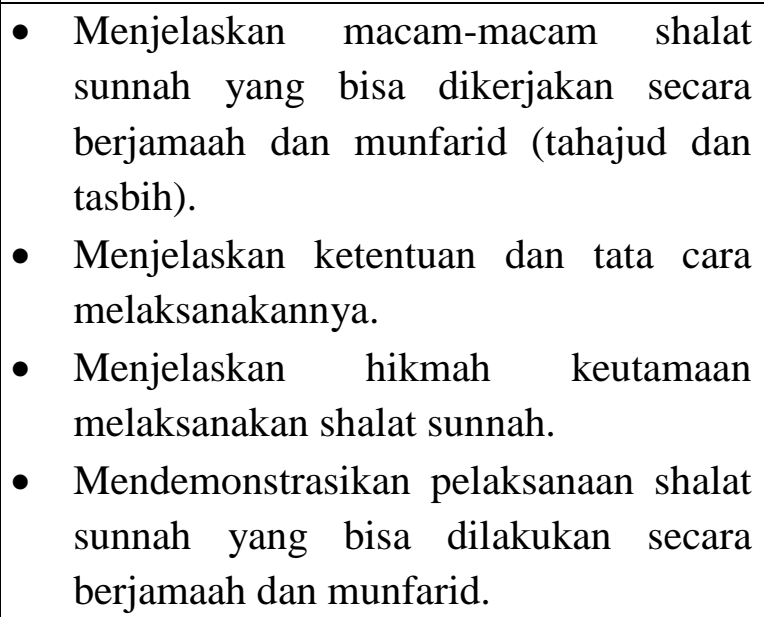 \\
\hline
\end{tabular}

Teknik dan alat dalam penelitian ini adalah pertama, observasi dimana dengan menggunakan lembar observasi. Kedua, tes dimana tes yang dilakukan berupa tes obyektif dengan bentuk pilihan ganda sebanyak 10 soal. Yang ketiga, dokumentasi merupakan teknik untuk mengumpulkan data yang secara tidak lansung melalui dokumen, baik berupa gambar ataupun video (Mahmud, 183: 2011). Adapun teknik analisis datanya yaitu dengan menganalisis hasil observasi dengan menggunakan rumus perhitungan sebagai berikut:

Tingkat keberhasilan $=\frac{\text { Jumlah aktivitas yang diperoleh }}{\text { Jumlah skor maksimal }} \times 100 \%$.

Dengan kriteria sebagai berikut:

Baik sekali $=80-100$

Baik $\quad=66-79$

Cukup $\quad=56-65$

Kurang $\quad=40-55$

Gagal $\quad=30-39$

Kemudian untuk menganalisis hasil belajar siswa itu dengan menggunakan rumus perhitungan sebagai berikut:

Menghitung nilai rata-rata $X=\frac{\sum X}{\sum N}$

Keterangan:

$\mathrm{X}=$ Nilai rata - rata 
$\sum \mathrm{X}=$ Jumlah semua nilai siswa

$\sum \mathrm{N}=$ Jumlah siswa

kemudian menghitung ketuntasan belajarnya dengan rumus perhitungan sebagai berikut:

Ketuntasan klasikal $=\frac{\text { Jumlah siswa yang tuntas }}{\text { Jumlah seluruh siswa }} \times 100 \%$

Ketuntasan individu $=\frac{\text { Jumlah skor yang diperoleh }}{\text { Jumlah skor maksimum }} \times 100 \%$

Penelitian ini dikatakan berhasil apabila hasil belajar siswa pada mata pelajaran PAI di kelas 8.5 ini mecapai indikator ketuntasan belajarnya minimal $80 \%$ dengan nilai KKM 76 yang telah ditetapkan oleh sekolah.

\section{HASIL KAJIAN DAN PEMBAHASAN}

Menurut Agus Suprijono (2013:61), Model pembelajaran kooperatif ini dikembangkan untuk mencapai hasil belajar yang berupa prestasi akademik, toleransi, menerima keragaman, dan pengembangan keterampilan sosial. Untuk mencapai hasil belajar itu model pembelajaran kooperatif menuntut kerjasama dan interdependensi peserta didik dalam struktur tugas, struktur tujuan, dan sturktur reward-nya. Setiap model pembelajaran pasti memiliki sebuah prinsip. Bagitu juga dalam menggunakan model belajar cooperative learning di dalam kelas, ada beberapa konsep mendasar yang harus diperhatikan dan diupayakan oleh seorang guru. Menurut Stahl (Solihatin dan Raharjo, 2009:7) prinsip-prinsip dasar tersebut adalah sebagai berikut: Perumusan tujuan belajar siswa harus jelas, Penerimaan yang menyeluruh oleh siswa tentang tujuan belajar, Ketergantungan yang berifat positif, Interaksi yang bersifat terbuka, Tanggung jawab individu, Kelompok bersifat heterogen, Interaksi sikap dan perilaku sosial yangg positif, Tindak lanjut (follow up) dan Kepuasan dalam belajar.

Menurut Darmadi (2017:102), Talking chips dalam pembelajaran kooperatif adalah sebuah model pembelajaran yang dilakukan dalam bentuk kelompok kecil yang terdiri dari 4-5 orang setiap kelompoknya, dan dari masing-masing anggota kelompok itu memiliki beberapa kartu yang dapat digunakan untuk menandai apabila mereka telah mengeluarkan pendapatnya ataupun sarannya dan kemudian meletakan kartu tersebut di atas meja. Menurut Sonia dalam talking chips (A book of multiple intelligence exercise from spain), talking chpis mempunyai dua proses yang penting yaitu, Proses sosial dan proses dalam penguasaan materi. Proses sosial ini memilki peran penting dalam model talking chips, karena selama penerapan model tersebut siswa dituntut untuk dapat bekerja sama dengan individu lain dalam kelompoknya, sehingga setiap siswa tersebut mampu membangun pengetahuan baru mereka didalam satu lingkungan sosial pada kelompoknya. Kemudian dalam proses penguasaan materinya, karena adanya bentuk kelompok dalam pembelajaran setiap siswa dapat belajar untuk berdiskusi, saling mengeluarkan pendapat ataupun memperjelas suatu gagasan, dan konsep materi yang mereka pelajari, serta dapat memecahkan masalah yang diberikan oleh guru (Darmadi, 2017:105).

Menurut Kagan (Darmadi, 2017:103), dalam pelaksanaan taking chips langkahlangkahnya adalah sebagai berikut: 
1) Guru membagi siswa kedalam kelompok kecil, sekitar 4-6 orang perkelompok.

2) Guru meminta setiap kelompok mendiskusikan materi pelajaran.

3) Setiap anggota kelompok diberi kartu atau chips (kartu untuk berbicara/ penanda sudah berbicara) biasanya dua sampai tiga kartu.

4) Setiap kali seorang anggota kelompok menyampaikan pendapatnya dalam diskusi, ia harus meletakan satu kartunya ditengah kelompok atau ditengah meja.

5) Setiap anggota kelompok diperkenankan menambah pendapatnya sampai kartunya habis. Jika kartu yang dimilikinya habis, ia tidak boleh berbicara lagi sampai semua anggota kelompoknya menghabiskan kartu mereka.

6) Jika semua kartu telah habis, sedangkan tugas belum selesai, kelompok boleh mengambil kesempatan untuk membagi-bagi kartu lagi dan diskusi dapat diteruskan kembali.

Kelebihannya adalah dapat mengatasi hambatan pemerataan kesempatan yang sering mewarnai kerja kelompok. Karena biasanya dalam kelompok ada yang selalu dominan banyak bicara dan ada juga yang pasif dan hanya mengandalkan kepada yang aktif. Sedangkan kekurangannya adalah guru dituntut untuk dapat mengawasi setiap siswa yang ada dikelas.

Penelitian ini dimulai dari tahap perencanaan, tindakan, observasi, dan refleksi pembelajaran pada setiap siklusnya. Pada setiap setiap siklusnya peneliti mengadakan kegiatan pretest-psotest. Sebegai tindakan untuk mengetahui kemampuan siswa sebelum masuk pada materi pembelajaran yang akan disampaikan dan setelah materi di sampaikan dengan penerapan model pembelajaran kooperatif tipe talking chips.

\section{1) Perencanaan}

Pada tahap ini, peneliti melakukan persiapan sebagai berikut: Pertama, peneliti menyusun Rencana Pelaksanaan Pembelajaran (RPP) sesuai dengan langkah-langkah model pembelajaran kooperatif tipe talking chips. Kedua, peneliti mempersiapkan media pembelajaran berupa kepingan kartu-kartu. Ketiga, peneliti menyusun format lembar observasi aktivitas guru dan siswa selama proses pembelajaran berlangsung. Keempat, peneliti menyusun instrumen tes, meliputi kisi-kisi soal dan soal tes untuk pretest dan postest.

2) Pelaksanaan

Pada tahap pelaksanaan ini yaitu melaksanakan pembelajaran dengan menggunnakan model pembelajaran kooperatif tipe talking chips pada mata pelajaran PAI materi shalat sunnah, yang sesuai dengan RPP yang tlah disusun.

3) Pengamatan

Pengamatan ini dilaksanakan pada saat pembelajaran. Tahap ini dilakukan untuk mengetahui sejauh mana aktivitas guru mengajar dan aktivitas siswa yang belajar dengan menggunakan model pembelajaran kooperatif tipe talking chips.

4) Refleksi

Tahap ini dilakukan untuk menindak lanjuti kekurangan dalam proses pembelajaran pada setiap siklusnya. 
Abdul Majid (2012: 1088), istilah pembelajaran (instruction) ini memiliki makna sebagai upaya untuk membelajarkan seseorang individu ataupun sekelompok orang melalui berbagai macam usaha baik melalaui strategi, metode, dan pendekatan belajar yang menuju kearah pencapaian tujuan yang telah direncanakan sebelumnya. Dalam melaksanakan pembelajaran, agar dapat mencapai hasil yang lebih optimal perlu memperhatikan beberapa prinsip pembelajaran. Menurut Gagne dalam buku condition of learning (Evelin dan Hartini, 2010:16) mengemukakan sembilan prinsip yang dapat dilakukan guru dalam melaksanakan pembelajaran, yaitu sebagai berikut: menarik perhatian, menyampaikan tujuan pembelajaran, mengingatkan konsep, menyampaikan materi pelajaran, memeberikan bimbingan belajar, memperoleh kinerja siswa, memberikan balikan, menilai hasil belajar dan memperkuat retensi dan transfer belajar.

Menurut Nana sudjana, hasil belajar siswa pada dasarnya adalah sebuah perubahan tingkah laku yang merupakan hasil dari belajar yang mencakup bidang kognitif, afektif, dan psikomotoris (2002:3). Slameto (2013:54) mengemukakan faktor yang mempengaruhi hasil belajar siswa itu ada dua faktor, yaitu faktor intern, meliputi faktor jasmani, psikologis dan kelelahan. Dan faktor ekstern, meliputi faktor keluarga, sekolah dan masyarakat.

Menurut Abdul Majid, ruang lingkup mata pelajaran pendidikan agama islam secara keseluruhannya meliputi Al-Quran dan Al-Hadis, keimanan, ahlak, fiqih/ ibadah, dan sejarah, sekaligus menggambarkan bahwa ruang lingkup pendidikan agama islam mencakup perwujudan keserasian, keselarasan, dan keseimbangan hubungan manusia dengan Allah Swt, diri sendiri, sesama manusia, mahluk lainnya maupun lingkungannya (2012:13)

Setelah dilakukan tindakan dengan menggunakan model pembelajaran kooperatif tipe talking chips pada mata pelajaran PAI materi shalat sunnah, aktivitas dan hasil belajar siswa mengalami peningkatan dilihat dari setiap siklusnya. Aktivitas siswa mengalami peningkatan dari setiap siklus yang telah dilakukannya. Pada siklus I, aktvitas siswa dalam mengikuti proses pembelajaran baru mencapai pada kriteria baik yaitu hanya sebesar 70,83\%. Pada siklus II sebesar $85,41 \%$ dengan kriteria sangat baik. Dan pada siklus III mencapai sebesar 91,66 dengan kriteria sangat baik.

Hasil belajar siswa pada setiap siklus pun mengalami peningkatan, pada siklus I pertemuan pertama, hasil pretest nilai rata-ratanya sebesar 55\% dengan hanya 4 siswa yang tuntas dari 30 orang siswa dengan persentase ketuntasan belajar klasikal sebesar $13.33 \%$. Sedangkan untuk hasil postest, nilai rata-ratanya sebesar $68.66 \%$ dengan jumlah siswa yang tuntas sebanyak 13 orang dari 30 siswa dengan persentase ketuntasan belajar klasikal sebesar $43.33 \%$. Pada siklus I pertemuan kedua, hasil pretest siswa dengan nilai rata-ratanya sebesar 56.66\% dengan jumlah 6 siswa yang tuntas dari 30 orang siswa dengan persentase ketuntasan belajar klasikal sebesar 20\%. Sedangkan untuk hasil postest, nilai rata-ratanya sebesar $75 \%$ dengan jumlah siswa yang tuntas sebanyak 17 orang dari 30 siswa dengan persentase ketuntasan belajar klasikal sebesar $56.66 \%$. Pada siklus II pertemuan pertama, hasil pretest siswa dengan nilai rata-ratanya sebesar $67 \%$ dengan jumlah 9 siswa yang tuntas dari 30 orang siswa dengan persentase 
ketuntasan belajar klasikal sebesar 30\%. Sedangkan untuk hasil postest, nilai rataratanya sebesar $80 \%$ dengan jumlah siswa yang tuntas sebanyak 22 orang dari 30 siswa dengan persentase ketuntasan belajar klasikal sebesar 73.33\%. Pada siklus II kedua keempat, hasil pretest siswa dengan nilai rata-ratanya sebesar $70.66 \%$ dengan jumlah 13 siswa yang tuntas dari 30 orang siswa dengan persentase ketuntasan belajar klasikal sebesar $43.33 \%$. Sedangkan untuk hasil postest, nilai rata-ratanya sebesar $82.66 \%$ dengan jumlah siswa yang tuntas sebanyak 24 orang dari 30 siswa dengan persentase ketuntasan belajar klasikal sebesar $80 \%$. Pada siklus III pertemuan pertama, hasil pretest siswa dengan nilai rata-ratanya sebesar $71.33 \%$ dengan jumlah 15 siswa yang tuntas dari 30 orang siswa dengan persentase ketuntasan belajar klasikal sebesar 50\%. Sedangkan untuk hasil postest, nilai rata-ratanya sebesar $85 \%$ dengan jumlah siswa yang tuntas sebanyak 27 orang dari 30 siswa dengan persentase ketuntasan belajar klasikal sebesar 90\%. Berdasarkan uraian pada setiap pertemuan tersebut, dapat dilihat dari pertemuan pertama sampai pertemuan kelima mengalami peningkatan yang signifikan. Adapun jika digambarkan dalam grafik adalah sebagai berikut:

\section{Gambar 4.1 Peningkatan Hasil Belajar Siswa}

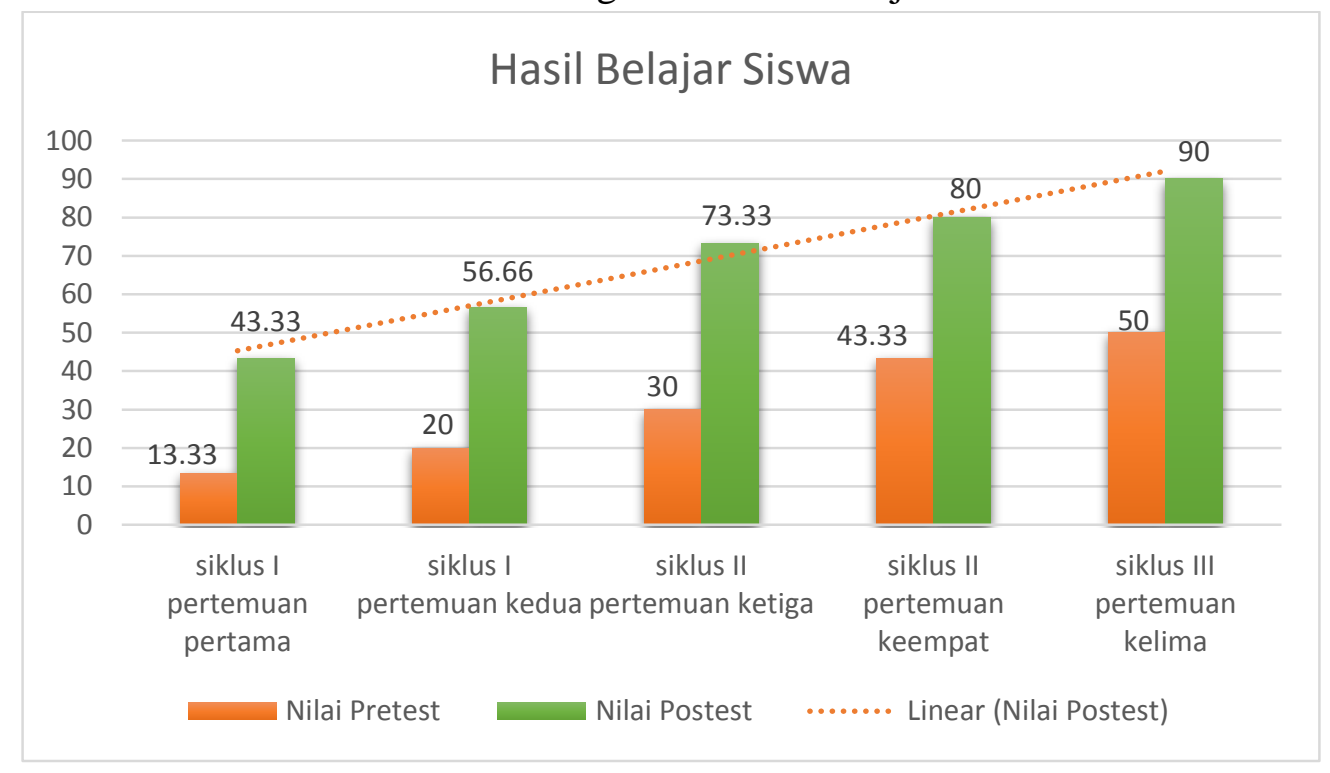

Berdasarkan grafik di atas, digambarkan bahwa ada peningkatan hasil belajar siswa pada setiap pertemuan dalam siklusnya. Pada pertemuan pertama dalam siklus I, kentutasan belajar klasikal siswa mencapai $43.33 \%$. Kemudian pada pertemuan kedua siklus I, ketuntasan belajar klasikal siswa mengalami peningkatan menjadi $56.66 \%$. Kemudian pada pertemuan pertama siklus II, ketuntasan belajar klasikal siswa meningkat lagi menjadi $73.33 \%$. Kemudian pada pertemuan kedua siklus II, ketuntasan belajar klasikal siswa mencapai $80 \%$. Kemudian pada pertemuan pertama siklus III, peningkatan ketuntasan belajar klasikal siswa meningkat mencapai $90 \%$.

Grafik di atas menunjukan peningkatan hasil belajar siswa pada setiap siklusnya. Hal ini dikarenakan penggunaan model pembelajaran kooperatif tipe talking chips. 
Sholihatin dan Raharjo (2009:4) mengemukakan, Cooperative learning memiliki arti sebagai sikap bekerja sama dan saling membantu dalam sebuah sturktur kelompok yang teratur, yang melibatkan dua orang atau lebih. Dalam sebuah kelompok keberhasilan kerja kelompok itu sangat dipengaruhi oleh adanya keterlibatan setiap individu dalam kelompoknya. Jika model pembelajaran yang diterapkan oleh guru tidak sesuai dengan tujuan dan kemampuan peserta didik, maka peserta didik akan gagal dalam belajrnya. Peserta didik harus dibiasakan bertanggung jawab terhadap kewajibannya dalam belajar. Proses pembelajaran bukan lah hanya untuk menerima pengetahuan, melainkan untuk proses membangun pengetahuan dimana peserta didik yang mencari tahu dan pendidik hanya memfasilitasi agar kegiatan pembelajaran dapat lebih bermakna.

\section{SIMPULAN}

Berdasarkan hasil Penelitian Tindakan Kelas pada kelas VIII 5 SMPN 4 Cikarang Timur, maka diperoleh kesimpulan sebagai berikut: Adanya peningkatan hasil belajar siswa pada setiap pertemuan dalam setiap siklusnya, setelah menggunakan model pembelajaran kooperatif tipe talking chips. Dimana sebelumnya hanya menggunakan metode ceramah dan tanya jawab yang berifat konvensional. Selain itu juga aktivitas siswa pada setiap siklusnya selama pembelajaran pun meningkat, meskipun ada beberapa siswa yang terlihat masih belum aktif dan cenderung diam. Hal ini dapat diambil kesimpulan bahwa dengan menggunakan model pembelajaran kooperatif tipe talking ini dapat meningkatkan hasil belajar siswa dan dapat memperbaiki proses pembelajaran menjadi lebih efektif. 


\section{DAFTAR PUSTAKA}

Alim, Muhammad. 2011. Pendidikan Agama Islam (Upaya Pembentukan Pemikiran dan KepribadiannMuslim). Bandung: PT. Remaja Rosdakarya.

Darmadi. 2017. Pengembangan Model Dan Metode Pembelajaran Dalam Dinamika Belajar Siswa. Yogyakarta: Deepublish.

Kunandar. 2013. Langkah Mudah Penelitian Tindakan Kelas Sebagai Pengembangan Profesi Guru. Jakarta: Rajawali Pers.

Majid, Abdul. 2012. Belajar Dan Pebelajaran Pendidikan Agama Islam. Bandung: PT Remaja Rosdakarya.

Salahudin, Anas. 2015. Penelitian Tindakan Kelas. Jakarta: CV Pustaka Setia.

Siregar, Eveline, dan Hartini Nara. 2010. Teori Belajar Dan Pembelajaran. Bogor: Ghalia Indonesia.

Sudjana, Nana. 2012. Dasar - Dasar Proses Belajar Mengajar. Bandung: Sinar Baru Algesindo.

Suprijono, Agus. 2017. Cooperative Learning Teori Dan Aplikasi PAIKEM. Yogyakarta: Pustaka Belajar.

Syah, Muhibbin. 2012. Psikologi Belajar. Jakarta: PT Raja Grafindo Persada.

Tuti, Hayati. 2013. Evaluasi Pembelajaran. Bandung: CV Insan Mandiri. 